\title{
Review of dexamethasone administration for management of complications in postoperative third molar surgery
}

\author{
Diane Isabel Selvido ${ }^{1}$, Bishwa Prakash Bhattarai ${ }^{1}$, Nattisa Niyomtham ${ }^{1}$, Apiwat Riddhabhaya ${ }^{1}$, \\ Kadkao Vongsawan ${ }^{1}$, Verasak Pairuchvej ${ }^{2}$, Natthamet Wongsirichat ${ }^{1}$ \\ ${ }^{I}$ Department of Oral and Maxillofacial Surgery, International College of Dentistry, Walailak University, \\ ${ }^{2}$ Thai Board of Oral \& Maxillofacial Surgery, Bangkok, Thailand
}

\begin{abstract}
J Korean Assoc Oral Maxillofac Surg 2021;47:341-350)
Dexamethasone has been used in oral and maxillofacial surgery for postoperative pain, swelling, and trismus following third molar surgeries. It is a potent and powerful drug that can alleviate the aforementioned postoperative sequelae. Dexamethasone is responsible for inhibiting the release of inflammatory mediators in the inflammation process to improve patient quality of life after surgical intervention. There are several available routes of administering dexamethasone. This article will help determine the suggested routes of administration, dosage, parameters, and dexamethasone timing for third molar surgeries.
\end{abstract}

Key words: Administration, Dexamethasone, Techniques, Inflammation, Quality of life [paper submitted 2020. 9. 12 / revised 1st 2020. 12. 13, 2nd 2021. 1. 11 / accepted 2021. 2. 9]

\section{Introduction}

Techniques for reducing pain or postoperative complications in the field of oral and maxillofacial surgery have emerged progressively over the years. However, it remains a common issue in the dental setting. Prescription of drugs pertaining to pain control, especially narcotics, has been widespread after dental surgeries. However, since the outcomes of dental surgeries are unpredictable, analgesic drugs like narcotics can be inadequate for pain relief.

Another method suggested is the use of corticosteroids, one of the most effective medications to control postoperative pain and inflammation ${ }^{1,2}$. Glucocorticosteroids are well known to suppress inflammation and are utilized in oral surgeries to relieve pain and reduce trismus and swelling.

\footnotetext{
Natthamet Wongsirichat

Department of Oral and Maxillofacial Surgery, International College of Dentistry, Walailak University, 979/42-46 Phahonyothin Rd, 19th Floor SM Tower, Phaya Thai, Bangkok 10400, Thailand

TEL: +66-22990935

E-mail:natthamet.wo@mail.wu.ac.th

ORCID: https://orcid.org/0000-0003-3005-2680
}

(c) This is an open-access article distributed under the terms of the Creative Commons Attribution Non-Commercial License (http://creativecommons.org/ licenses/by-nc/4.0/), which permits unrestricted non-commercial use, distribution, and reproduction in any medium, provided the original work is properly cited.

Copyright (C) 2021 The Korean Association of Oral and Maxillofacial Surgeons.
One of the most potent steroidal inflammatory drugs is dexamethasone ${ }^{3}$, a synthetic glucocorticosteroid that has no mineralocorticoid effect. This drug has a minimal unfavorable impact on leukocyte chemotaxis, which indicates movement of cells outside the circulatory system toward the site of injury ${ }^{4}$. This glucocorticosteroid is at least 25 to 50 times more potent than hydrocortisone and is one of the most potent antiinflammatory drugs. At inflammatory doses, dexamethasone lacks the sodium-maintaining properties of hydrocortisone ${ }^{5}$. Glucocorticoids such as dexamethasone also control the rate of synthesis of anti-inflammatory genes in molecular mechanisms ${ }^{6}$ and are similar to hormones produced by the adrenal glands ${ }^{7}$.

There have been many published clinical trials on the capabilities of dexamethasone, emphasizing the route of administration and potential contributions to the field of oral and maxillofacial surgery. However, the introduction of new approaches and pathways has called into question the efficacy among the methods. Consequently, this literature review will help determine the suggested routes of administration, dosage, parameters, and dexamethasone timing for third molar surgeries. 


\section{Dexamethasone in general use}

Since dexamethasone is a corticosteroid, it is used widely due to its anti-inflammatory activity and proven safety. It inhibits vascular dilation and fluid transudation and decreases cell turnover through inhibition and chemotaxis of inflammatory cells that produce several inflammatory mediators ${ }^{2}$. For this reason, dexamethasone is suggested even for major procedures such as orthognathic surgeries ${ }^{8}$.

The application of dexamethasone is not without limitations. Contraindications are diabetes mellitus, peptic ulcers, tuberculosis, hypertension, ocular herpes, glaucoma, Cushing's syndrome, renal insufficiency, and pregnancy ${ }^{9}$. The effects on these conditions indicate the impact of dexamethasone on various endocrine and metabolic functions. In pregnancy, the drug can lead to adrenal suppression of the fetus ${ }^{10}$. However, dexamethasone is accepted widely as a treatment for allergies, inflammation, and preoperative and postoperative supportive therapies ${ }^{5}$ and commonly is studied in conjunction with surgery.

Dexamethasone has a relative anti-inflammatory potency of 25 with a plasma half-life of 100 to 300 minutes and a biological half-life of 36 to 72 hours. According to Neupert et al. ${ }^{11}$, a $4 \mathrm{mg}$ dose can generate five times the body's standard physiological output of cortisol. The onset of dexamethasone is presumed to be 1 to 2 hours - enough time to disperse along the cell membrane ${ }^{12}$. Corticosteroids are claimed to be functioning at their full potential during the first 24 hours after surgery, with the effects potentially lasting for three days ${ }^{2}$. The postoperative outcomes are triggered by inflammatory responses that lead to strong vasodilating pro-inflammatory mediators ${ }^{13}$. Initially, postoperative swelling is due to inflammation, a protective response that eventually leads to injury. Characteristics of inflammation are as follows: redness, swelling, heat, pain, and loss of tissue function ${ }^{14}$. Upon injury, the body has the capability of inducing a chemical signaling cascade that activates responses that will lead to healing of the injured tissues. Leukocyte chemotaxis will mobilize from the systemic circulation to the target area ${ }^{15}$.

\section{Dexamethasone in third molar surgeries}

In dentistry, dexamethasone usually is studied with third molar surgeries. Third molar extraction is one of the most common procedures carried out by oral and maxillofacial surgeons. Surgical removal of third molars usually requires bone removal, flap reflection, and tooth sectioning. Injuries caused by manipulation of the surrounding tissue and association with postoperative sequelae such as pain, edema, and trismus reduce the quality of life of the patient. Typically, with a patient experiencing moderate to severe pain, analgesics are prescribed. Given the potential of non-steroidal antiinflammatory drugs (NSAID) to cause acidity that induces a more severe side effect in some patients, the type and amount of analgesics must be selected carefully to avoid potential adverse side effects ${ }^{16}$.

Pain, swelling, and trismus occur predominantly because of inflammation following third molar surgeries. Pain is a result of inflammation caused by tissue injury ${ }^{17,18}$. Postoperative pain increases the patient's anxiety and suffering and significantly influences wound health and healing predictability ${ }^{19}$. Although the various pain measurements have limited validity, they should accurately describe patient pain ${ }^{20}$. One of the most applied measurements is the visual analogue scale (VAS). This parameter is utilized to determine the subjective pain experience of patients, especially those who underwent oral and maxillofacial surgeries ${ }^{21}$. Multiple studies have used VAS to indicate pain response with dexamethasone administration ${ }^{7,13,22-28}$. Other studies have relied on analgesic intake along with VAS in determining pain levels ${ }^{7,23}$. It was emphasized in a study by Laureano Filho et al. ${ }^{22}$ that dexamethasone has a minimal effect on pain but a large influence on swelling and trismus. Additionally, VAS results by Gozali et al. ${ }^{23}$ showed pain reduction only with the sublingual route.

Swelling can occur where the bone, gingiva, and mucosa are manipulated during prolonged surgery. There is no single method to measure swelling because linear estimations are not reproducible ${ }^{29}$. Studies involving dexamethasone usually contain direct swelling measurements at six anatomical points and determining the mean of the linear dimensions (angle of the mandible, tragus, commissure of the lips, nasal border, pogonion, and lateral to the outer canthus of the eye). The points generally are described based on planes from the tragus of the ear to the corner of the mouth, from the gonion to the commissure of the lips, and from the outer canthus of the eye to the gonion ${ }^{13,22,24,28}$. Several studies only measured four points based on planes from the tragus of the ear to the commissure of the mouth, outer canthus of the eye, and angle of the mandible or gonion ${ }^{25-27,30}$. Majid and Mahmood ${ }^{31}$ assessed the two measurements from the tragus of the eye to the midline (pogonion) and to the outer canthus of the eye to the gonion.

Trismus is limitation in mouth opening caused by immobilized facial musculature and nervous structures to reduce 
discomfort after surgery ${ }^{13,22,32}$. Several studies involving dexamethasone have quantified trismus by measuring the interincisal distance with a ruler or a caliper. This parameter usually is measured as the distance between the incisal angles of the maxillary and mandibular central incisors at maximum opening ${ }^{13,22-28}$. However, Al-Shamiri et al. ${ }^{13}$ created a different approach by calculating the difference between maximum opening preoperatively and postoperatively.

It has been reported that patients require a smaller intake of analgesics like NSAIDs when steroids such as dexamethasone are prescribed. The reason for this is because dexamethasone in some studies appears to reduce pain after surgery $^{23,33,34}$. Bamgbose et al. ${ }^{35}$ suggested that combined treatment with NSAIDs and corticosteroids like dexamethasone is advantageous in reducing postoperative sequelae without complications. Nonetheless, the intake of corticosteroids depends on procedure difficulty and should not be applied in all cases of third molar surgeries ${ }^{36}$.

Quality of life also has been assessed with dexamethasone in third molar studies. As defined by Majid ${ }^{19}$, quality of life is the patient's ability to perceive the outcomes of the conditions they are experiencing and involves impacts on daily life, social abilities, and physical and mental well-being. This tool usually is comprised of standardized or modified questionnaires that apply to a particular situation and usually are answered subjectively ${ }^{37}$. The outcomes of third molar surgical extractions have been correlated with the quality of life of the patients. Tiwana et al. ${ }^{38}$ mentioned that intravenous corticosteroids could decrease pain and swelling, thus improving patient quality of life.

\section{Dexamethasone mechanism}

In inflammation, injuries create cell membrane dysfunction to allow conversion of phospholipids into arachidonic acid by enzyme phospholipase A (PLA2), an essential chemical mediator that plays a crucial role in the cellular phospholipid bilayer. This transition will lead to synthesis of prostaglandins and thromboxane by cyclooxygenase (COX) of and leukotrienes through lipoxygenase and other related substances that trigger inflammatory responses in the initial phases ${ }^{24,39,40}$. These responses are responsible for peripheral sensitization, which increases the excitability of dorsal horn neurons, followed by central sensitization. Once central sensitization is established, signals transmitted through $\mathrm{A} \beta$ fibers from lowthreshold mechanoreceptors are perceived as pain at dorsal horn neurons with high excitability. In addition, since A $\delta$ fi- bers and $\mathrm{C}$ fibers from nociceptors are under peripheral sensitization, the pain is enhanced and sustained. Once this central sensitization is established, patients will respond poorly to analgesics ${ }^{41}$.

In the concept of pre-emptive analgesia, postoperative pain is minimized by preventing central sensitization before surgery. When pre-emptive analgesia is provided before surgery, central sensitization is suppressed, and postoperative hyperesthesia does not occur ${ }^{42}$. Other mediators that play a crucial role in inducing inflammation are bradykinin, prostaglandins, and leukotrienes ${ }^{43-45}$. According to Lerner et al. ${ }^{46}$, bradykinin is a nonapeptide that activates prostaglandin. Corticosteroids like dexamethasone have been observed to inhibit the release of bradykinin-produced prostaglandin (PGE2), reducing inflammation at the early stages. On the other hand, leukotrienes have a hypoalgesia effect that is essential in modulating inflammatory pain caused by kinins in the system ${ }^{45}$.

Inflammatory responses such as swelling occur gradually, with a peak at 48 hours after surgical removal of the teeth ${ }^{44,47}$. Corticosteroids and NSAIDs block on of the same pathways leading to an inflammatory reaction ${ }^{7}$. NSAIDs block the cyclooxygenase system, while corticosteroids block both the cyclooxygenase and lipoxygenase systems ${ }^{40}$. Based on this, corticosteroids are superior in reducing the effects of chemical mediators and can decrease swelling and trismus compared to NSAIDs ${ }^{22}$.

\section{Routes of Administration}

There are several routes to administering dexamethasone that had been attempted and studied in surgeries of different teeth. There remains no definite consensus about the best treatment approach because advantages and disadvantages exist in every method tested ${ }^{48,49}$. The administration of corticosteroids through submucosal, intramuscular, intra-alveolar, or intravenous route reduced postoperative pain after third molar surgery ${ }^{50}$.

\section{Oral route}

According to Al-Shamiri et al. ${ }^{13}, 8 \mathrm{mg}$ oral dexamethasone either preoperatively or postoperatively lessens the postoperative complications of third molar surgeries, with their findings leaning toward preoperative administration. Sabhlok et al. ${ }^{50}$ used $4 \mathrm{mg}$ of oral dexamethasone postoperatively every day for five days, demonstrating that it is useful for treating pain and trismus. Moreover, de Sousa Santos et al. ${ }^{51}$ con- 
cluded that oral dexamethasone with tramadol has favorable effects in controlling the postoperative complications of third molar surgeries. The oral route depends on patient compliance and repeated intake to regulate blood level for successful outcomes, rendering it a debatable course of administration $^{52}$.

\section{Submucosal route}

According to Grossi et al. ${ }^{44}$, submucosally-administered dexamethasone can achieve positive postoperative edema results compared to other administration routes. Furthermore, they also stated that the submucosal route is advantageous from both the operator and patient point of view because of the ease of administration. Arora et al. ${ }^{53}$ found the same results using dexamethasone through the same route. Supporting the conclusions drawn by Grossi et al. ${ }^{44}$ and Arora et al. ${ }^{53}$, Khalida et al. ${ }^{25}$ demonstrated the positive effects of dexamethasone submucosally through reduction of discomfort following surgery. They mentioned that a sub-therapeutic dose of $4 \mathrm{mg}$ has nonsignificant systemic outcomes ${ }^{25}$. Likewise, Shah et al. ${ }^{33}$ stated that dexamethasone through this route improves patient quality of life. However, the intervention was performed for apicectomy in anterior maxillary teeth, not for third molar surgery ${ }^{33}$. These studies demonstrate the submucosal route as a widely popular technique ${ }^{54}$. In a 2016 metaanalysis by Moraschini et al. ${ }^{55}$ on submucosal administration of dexamethasone after third molar surgeries, there was significant decrease of swelling and pain in all studies but was no difference in trismus.

According to $\mathrm{Deo}^{56}$, quality of life decreased immediately after third molar surgery, leading to his conclusion that submucosal dexamethasone can maintain the quality of life. Other studies support this conclusion regarding submucosal dexamethasone ${ }^{19,31,57}$.

\section{Intravenous route}

Bamgbose et al. ${ }^{35}$ conducted a study using intravenous dexamethasone with a maximum of $16 \mathrm{mg}$ within 24 hours. Their findings complemented the amplified effects of dexamethasone when used with diclofenac sodium after third molar surgery ${ }^{35}$. Another study by Moore et al. ${ }^{58}$ concluded that a co-therapy of $10 \mathrm{mg}$ intravenous dexamethasone (preoperatively) with $50 \mathrm{mg}$ rofecoxib (intraoperative) was the most efficient in combating pain and trismus after third molar surgery compared to using intravenous dexamethasone intra- operatively.

\section{Intramuscular route}

Intramuscular injections were found to exhibit similar effects to the intravenous route. Klongnoi et al. ${ }^{48}$ mentioned enhanced postoperative pain relief and reduced swelling in impacted lower third molar surgeries with preoperative $8 \mathrm{mg}$ intramuscular dexamethasone injection in the deltoid muscle. Al-Dajani ${ }^{59}$ concluded that a single preoperative intramuscular dose of dexamethasone successfully minimized postoperative sequelae after surgical removal of third molar and improved comfort in performing day to day activities.

Coupled by the findings corresponding to intravenous and intramuscular administration, Majid and Mahmood's findings ${ }^{31}$ support the conclusion that intravenous and intramuscular routes of dexamethasone have positive effect on swelling and pain compared to other administration routes due to the higher plasma concentrations and long-lasting antiinflammatory effects of intramuscular injection.

In comparing the three routes cited above, in 2017, Vivek et al. ${ }^{60}$ studied $8 \mathrm{mg}$ dexamethasone through the three routes of administration of intravenous, intramuscular, and submucosal and determined that, aside from the faster onset and greater bioavailability of intravenous administration, the submucosal and intramuscular routes also can be used for control of pain and swelling with fewer possible complications compared to the intravenous route.

\section{Other novel approaches}

The administration of dexamethasone through the pterygomandibular space was studied by Latt et al. ${ }^{61}$ in 2016 . It was perceived that an $8 \mathrm{mg}$ dexamethasone dose administered through this route was sufficient in reducing swelling, pain, and trismus after third molar surgery ${ }^{61}$.

The sublingual route of dexamethasone was recommended by Gozali et al. ${ }^{23}$ for patient comfort in 2017. It was claimed to have a faster onset and, at the $8 \mathrm{mg}$ dose, was believed to be advantageous compared to the intramuscular method to alleviate effectively pain symptoms ${ }^{23}$.

Validating the evidence presented by Latt et al. ${ }^{61}$ and Gozali et al. ${ }^{23}$, a 2019 study by Moranon et $\mathrm{al}^{6}{ }^{62}$ found that injections of $8 \mathrm{mg}$ dexamethasone into the pterygomandibular or sublingual space were effective similarly in easing postoperative sequelae after third molar surgeries.

Graziani et al. ${ }^{36}$ studied dexamethasone in endo alveolar 
powder and submucosal routes and found comparable results for postoperative pain, swelling, and trismus. It is important to note that the topical dexamethasone used in their study had a more significant effect on trismus ${ }^{36}$.

The intra-masseteric approach was investigated by Nandi$\mathrm{ni}^{52}$ using $8 \mathrm{mg}$ dexamethasone, and they claimed that it was another way to reduce postoperative sequelae compared to the systemic approach. Moreover, some studies stated that the intra-masseteric and submucosal routes were more effective because the drug injection site is in proximity to the surgical area, allowing greater localized absorption with nonsignificant side effects ${ }^{52,56}$.

Another new method was reported in 2020, where the intraosseous route was utilized and compared to the submucosal route. Kaewkumnert et al. ${ }^{27}$ found that the latter was more efficacious than the former due to the possibility of heightened tension with discomfort created by intraosseous injection in the alveolar bone. A summary of respective techniques were presented in Table 1.

\section{Dosages}

The ideal dose of dexamethasone has yet to be determined $^{50}$. According to Antunes et al. ${ }^{3}$, the dosing is arbitrary depending on the severity of the issue and patient tolerance.

\section{1. $4 \mathrm{mg}$ dosage}

Neupert et al. ${ }^{11}$ reported that $4 \mathrm{mg}$ of intravenous dexamethasone exhibited no statistical differences in swelling and trismus compared to the sterile water control. On the other hand, Majid and Mahmood ${ }^{63}$ in 2011, concluded that $4 \mathrm{mg}$ dexamethasone through the submucosal route effectively controlled pain, swelling, and trismus compared to the intramuscular route. Another interesting study by Arora et al. ${ }^{53}$ in 2018 stated that no significant differences were observed when $4 \mathrm{mg}$ or $8 \mathrm{mg}$ was used after third molar surgeries, and that $4 \mathrm{mg}$ was sufficient in reducing edema after third molar surgeries.

\section{2. $8 \mathrm{mg}$ dosage}

A study by Laureano Filho et $\mathrm{al}^{22}$ in 2008, comparing the effectiveness of dosages of dexamethasone, indicated that 8 $\mathrm{mg}$ dexamethasone is more efficient in minimizing trismus and swelling compared to the lower dose of $4 \mathrm{mg}$. Chaudhary et al. ${ }^{64}$, however, assessed $8 \mathrm{mg}$ oral dexamethasone and 4

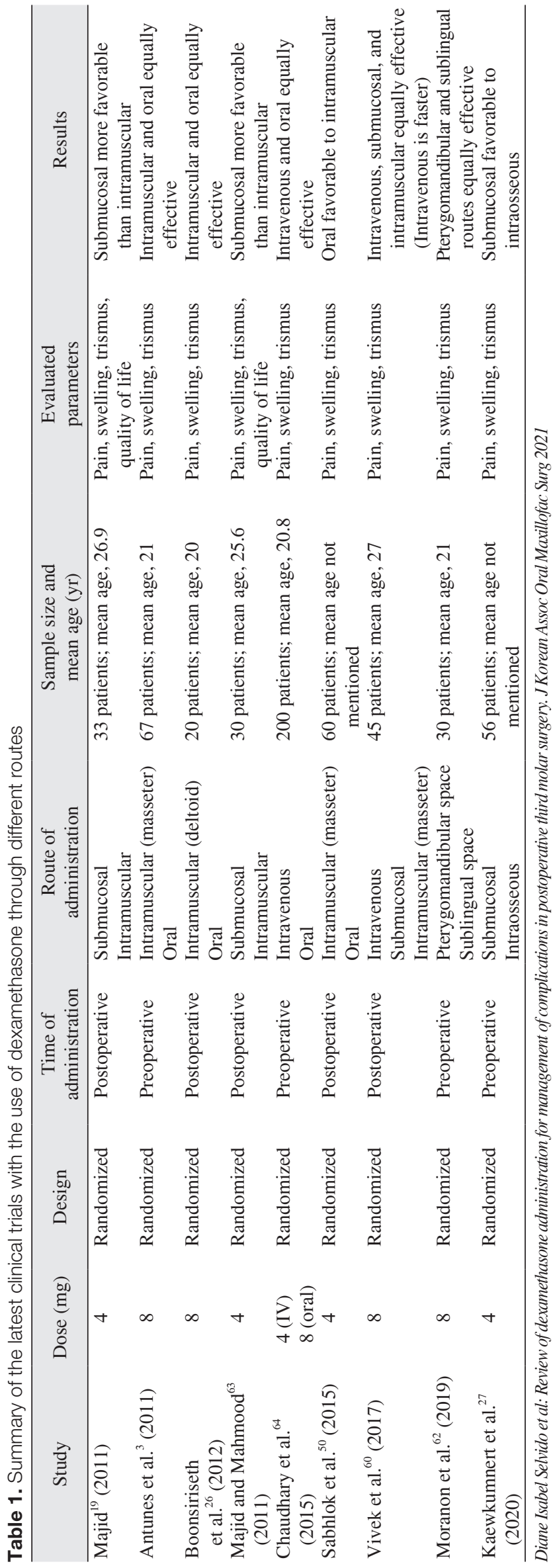


$\mathrm{mg}$ intravenous dexamethasone. Their results demonstrated that the former was as valuable as the latter in combating postoperative issues after third molar surgeries even if the two routes differed ${ }^{64}$. To date, there are no other studies to supplement the finding that $8 \mathrm{mg}$ dexamethasone is more effective than the $4 \mathrm{mg}$ option through a consistent route of administration. A supporting study of the two dosages was conducted by Grossi et al. ${ }^{44}$ and suggested that $4 \mathrm{mg}$ and 8 $\mathrm{mg}$ were effective equally in terms of eliminating edema.

\section{Timing of Administration}

Regarding whether we should use dexamethasone preoperatively, perioperatively, or postoperatively, Simone et al. ${ }^{7}$ indicated that the preoperative combination of dexamethasone and anti-inflammatory drugs was effective in minimizing pain during the postoperative period.

\section{Preoperative}

Ngeow and $\mathrm{Lim}^{65}$ also mentioned that corticosteroids were preferred before surgery before of commencement of inflammatory activity. Specifically, the rationale for preoperative use of dexamethasone includes preventing establishment of central sensitization caused by peripheral nociception activity secondary to surgical trauma. In the absence of local anesthesia, this process begins at the incision and continues during the intraoperative and postoperative periods ${ }^{7}$. Preoperative administration was favorable among studies comparing perioperative and postoperative administration ${ }^{13,66,67}$.

\section{Perioperative}

A systemic review and meta-analysis by Markiewicz et al. ${ }^{68}$ deduced that perioperative corticosteroids, in general, can lessen edema and trismus more than the control group in a mild to moderate manner, but with no conclusive evi- dence regarding pain outcomes. Graziani et al. ${ }^{36}$ reinforced this claim using dexamethasone, mentioning that the ease of operation with timing can decrease morbidity after surgery. Similarly, Mehra et al. ${ }^{69}$ stated that a perioperative dosage of dexamethasone had a tremendous impact by lessening postoperative side effects, but only for a short duration.

\section{Postoperative}

Studies regarding postoperative use of dexamethasone alone in preventing adverse effects on third molar surgeries are limited. Lima et al. ${ }^{70}$ used $4 \mathrm{mg}$ oral dexamethasone following third molar surgery in a clinical setting and found that all the postoperative sequelae had been addressed in contrast to the use of diclofenac sodium. Furthermore, concerning the timing, it is important to note that some studies found that dexamethasone injections before or after third molar surgeries to be equitably efficacious ${ }^{24,71}$. The comparisons between the different timing of administration are shown in Table 2.

\section{Difficulty of Surgery}

According to several authors, the Pell and Gregory Difficulty index exhibits questionable reliability. However, it is an important part of predicting postoperative ramifications after surgical removal of third molars when administered with dexamethasone ${ }^{36,42}$. The most common inclusion criteria in dexamethasone trials were Class II and Position $\mathrm{B}^{3,42,44,49,60,64,72,73}$. The use of corticosteroids, in general, is not applicable for every third molar surgery. Nevertheless, its administration can be important in cases of a certain degree of complexity $^{74,75}$.

\section{Adverse Effects}

Dexamethasone has been utilized in different conditions, including reducing postoperative nausea and pain after

Table 2. Studies on dexamethasone comparing preoperative and postoperative administrations for third molar surgeries

\begin{tabular}{|c|c|c|c|c|c|c|}
\hline Study & Design & $\begin{array}{l}\text { Dose } \\
(\mathrm{mg})\end{array}$ & $\begin{array}{c}\text { Time of } \\
\text { administration }\end{array}$ & Route & $\begin{array}{l}\text { Sample size and } \\
\text { mean age }(\mathrm{yr})\end{array}$ & Results \\
\hline Al-Shamiri et al. ${ }^{13}(2017)$ & RCT & 8 & Preop. or Postop. & Oral & 24 patients; N/A & Preop.>Postop. \\
\hline Latif Shah et al ${ }^{66}$ (2018) & RCT & 8 & Preop. or Postop. & Intramuscular & 150 patients; N/A & Preop.>Postop. \\
\hline Giri et al. ${ }^{24}(2019)$ & RCT & 8 & Preop. or Postop. & Intravenous & 100 patients; $27.7 \pm 9.7$ & Preop $=$ =Postop. \\
\hline Núñez-Díaz et al. ${ }^{67}$ (2020) & RCT & 4 & Preop. or Postop. & Intramuscular & 60 patients; N/A & Preop.>Postop. \\
\hline $\begin{array}{l}\text { Sitthisongkhram et al. } \\
\text { (2020) }\end{array}$ & RCT & 4 & Preop. or Postop. & Pterygomandibular & 27 patients; N/A & Preop. $=$ Postop. \\
\hline
\end{tabular}

(RCT: randomized controlled trial, Preop.: preoperative, Postop.: postoperative, N/A: mean ages not mentioned)

Diane Isabel Selvido et al: Review of dexamethasone administration for management of complications in postoperative third molar surgery. J Korean Assoc Oral Maxillofac Surg 2021 
general anesthesia ${ }^{15}$. For a long time, it has been utilized as a drug for reduction of postoperative sequelae. As general knowledge, most drugs have different adverse effects as they enter the body, regardless of administration route. While dexamethasone has been indicated to help with third molar surgeries because of its enhanced analgesic effects and decreasing discomfort during the postoperative period, it also has adverse effects that can impact healing.

In a systemic review and meta-analysis by Waldron et al. ${ }^{12}$, 45 studies exhibited routine wound healing without infection but increased blood glucose that was not sufficient to create drastic outcomes.

A review article by Caplan et al. ${ }^{76}$ states that patients taking glucocorticoids can encounter gastric irritation. Still, it was not enough to be at risk for peptic ulcer disease. A combination of NSAIDs and glucocorticoids is stated to increase the risk for peptic ulcer disease. Therefore, it is advised that patients who take them should undergo prophylactic doses with a proton pump inhibitor.

According to Bebawy ${ }^{77}$, gastric stress is more frequent during the perioperative periods. The immunological effects of dexamethasone are said to have possible apoptotic consequences on $\mathrm{T}$ lymphocytes and decrease the quantities of $\beta$ cells in moderate to high doses. In contrast to these findings, many studies have stated that there were no adverse reactions experienced by most of the participants in each study ${ }^{31,35,78}$. This evidence supports the finding that dexamethasone can be used safely and effectively.

\section{Conclusion}

With the evidence presented, dexamethasone used in third molar surgeries is effective regardless of route of administration, dosage, and timing. Dexamethasone is a corticosteroid that is highly potent for anti-inflammatory use since it suppresses effectively inflammatory mediators. Among all the elements reviewed, preoperative administration and submucosal route with a dosage of 4 to $8 \mathrm{mg}$ had the most impact on outcomes from most clinical trials. The results can vary by study and chosen parameters. Therefore, further studies are encouraged to maximize the effectiveness of this highly efficient drug.

\section{ORCID}

Diane Isabel Selvido, https://orcid.org/0000-0001-6232-6477

Bishwa Prakash Bhattarai, https://orcid.org/0000-0003-
3359-9032

Nattisa Niyomtham, https://orcid.org/0000-0003-2233918X

Apiwat Riddhabhaya, https://orcid.org/0000-0002-90932316

Kadkao Vongsawan, https://orcid.org/0000-0002-05372896

Verasak Pairuchvej, https://orcid.org/0000-0002-9566-2407

Natthamet Wongsirichat, https://orcid.org/0000-0003-30052680

\section{Authors' Contributions}

D.I.S. designed and wrote the manuscript. B.P.B. reviewed and edited the manuscript and tables. N.N. participated in the coordination of this review. N.W., V.P., K.V., and A.R. conceptualized and supervised the project. All authors read and approved the final manuscript.

\section{Conflict of Interest}

No potential conflict of interest relevant to this article was reported.

\section{References}

1. Mutlu I, Abubaker AO, Laskin DM. Narcotic prescribing habits and other methods of pain control by oral and maxillofacial surgeons after impacted third molar removal. J Oral Maxillofac Surg 2013;71:1500-3. https://doi.org/10.1016/j.joms.2013.04.031

2. Herrera-Briones FJ, Prados Sánchez E, Reyes Botella C, Vallecillo Capilla M. Update on the use of corticosteroids in third molar surgery: systematic review of the literature. Oral Surg Oral Med Oral Pathol Oral Radiol 2013;116:e342-51. https://doi.org/10.1016/ j.oooo.2012.02.027

3. Antunes AA, Avelar RL, Martins Neto EC, Frota R, Dias E. Effect of two routes of administration of dexamethasone on pain, edema, and trismus in impacted lower third molar surgery. Oral Maxillofac Surg 2011;15:217-23. https://doi.org/10.1007/s10006-011-0290-9

4. Kurihara A, Ohuchi K, Tsurufuji S. Reduction by dexamethasone of chemotactic activity in inflammatory exudates. Eur J Pharmacol 1984;101:11-6. https://doi.org/10.1016/0014-2999(84)90025-6

5. Messer EJ, Keller JJ. The use of intraoral dexamethasone after extraction of mandibular third molars. Oral Surg Oral Med Oral Pathol 1975;40:594-8. https://doi.org/10.1016/00304220(75)90369-2

6. Barnes PJ. Mechanisms and resistance in glucocorticoid control of inflammation. J Steroid Biochem Mol Biol 2010;120:76-85. https:// doi.org/10.1016/j.jsbmb.2010.02.018

7. Simone JL, Jorge WA, Horliana AC, Canaval TG, Tortamano IP. Comparative analysis of preemptive analgesic effect of dexamethasone and diclofenac following third molar surgery. Braz Oral Res 2013;27:266-71. https://doi.org/10.1590/S180683242013005000012

8. Weber CR, Griffin JM. Evaluation of dexamethasone for reducing postoperative edema and inflammatory response after orthogna- 
thic surgery. J Oral Maxillofac Surg 1994;52:35-9. https://doi. org/10.1016/0278-2391(94)90010-8

9. Dhanavelu P, Shanmugapriyan S, Ebenezer V, Balakrishnan B, Elumalai M. Dexamethasone for third molar surgery- a review. Int J Pharm Bio Sci 2013;4:9-13.

10. Stanbury RM, Graham EM. Systemic corticosteroid therapy--side effects and their management. Br J Ophthalmol 1998;82:704-8. https://doi.org/10.1136/bjo.82.6.704

11. Neupert EA 3rd, Lee JW, Philput CB, Gordon JR. Evaluation of dexamethasone for reduction of postsurgical sequelae of third molar removal. J Oral Maxillofac Surg 1992;50:1177-82; discussion 1182-3. https://doi.org/10.1016/0278-2391(92)90149-t

12. Waldron NH, Jones CA, Gan TJ, Allen TK, Habib AS. Impact of perioperative dexamethasone on postoperative analgesia and side-effects: systematic review and meta-analysis. Br J Anaesth 2013;110:191-200. https://doi.org/10.1093/bja/aes431

13. Al-Shamiri HM, Shawky M, Hassanein N. Comparative assessment of preoperative versus postoperative dexamethasone on postoperative complications following lower third molar surgical extraction. Int J Dent 2017;2017:1350375. https://doi. org/10.1155/2017/1350375

14. Takeuchi O, Akira S. Pattern recognition receptors and inflammation. Cell 2010;140:805-20. https://doi.org/10.1016/ j.cell.2010.01.022

15. Chen L, Deng H, Cui H, Fang J, Zuo Z, Deng J, et al. Inflammatory responses and inflammation-associated diseases in organs. Oncotarget 2017;9:7204-18. https://doi.org/10.18632/oncotarget.23208

16. Coulthard P, Esposito M, Renton TF, Worthington HV. Surgical techniques for the removal of mandibular wisdom teeth. Cochrane Database Syst Rev 2003;(7):CD004345. https://doi. org/10.1002/14651858.cd004345

17. Amaya F, Izumi Y, Matsuda M, Sasaki M. Tissue injury and related mediators of pain exacerbation. Curr Neuropharmacol 2013;11: 592-7. https://doi.org/10.2174/1570159X11311060003

18. Osunde OD, Adebola RA, Omeje UK. Management of inflammatory complications in third molar surgery: a review of the literature. Afr Health Sci 2011;11:530-7.

19. Majid OW. Submucosal dexamethasone injection improves quality of life measures after third molar surgery: a comparative study. J Oral Maxillofac Surg 2011;69:2289-97. https://doi.org/10.1016/ j.joms.2011.01.037

20. Isik K, Unsal A, Kalayci A, Durmus E. Comparison of three pain scales after impacted third molar surgery. Oral Surg Oral Med Oral Pathol Oral Radiol Endod 2011;112:715-8. https://doi.org/10.1016/ j.tripleo.2011.01.001

21. Sirintawat N, Sawang K, Chaiyasamut T, Wongsirichat N. Pain measurement in oral and maxillofacial surgery. J Dent Anesth Pain Med 2017;17:253-63. https://doi.org/10.17245/ jdapm.2017.17.4.253

22. Laureano Filho JR, Maurette PE, Allais M, Cotinho M, Fernandes C. Clinical comparative study of the effectiveness of two dosages of dexamethasone to control postoperative swelling, trismus and pain after the surgical extraction of mandibular impacted third molars. Med Oral Patol Oral Cir Bucal 2008;13:E129-32.

23. Gozali P, Boonsiriseth K, Kiattavornchareon S, Khanijou M, Wongsirichat N. Decreased post-operative pain using a sublingual injection of dexamethasone $(8 \mathrm{mg})$ in lower third molar surgery. J Dent Anesth Pain Med 2017;17:47-53. https://doi.org/10.17245/ jdapm.2017.17.1.47

24. Giri KY, Joshi A, Rastogi S, Dandriyal R, Indra B Prasad N, Singh $\mathrm{HP}$, et al. Efficacy of intravenous dexamethasone administered preoperatively and postoperatively on pain, swelling, and trismus following third molar surgery. A comparative study. Oral Surg 2019; 12:110-7. https://doi.org/10.1111/ors.12399

25. Khalida B, Fazal M, Muntaha S, Khan K. Effect of submucosal injection of dexamethasone on post-operative swelling and trismus following impacted mandibular third molar surgery. Pakistan Oral
Dent J 2017;37:231-4.

26. Boonsiriseth K, Klongnoi B, Sirintawat N, Saengsirinavin C, Wongsirichat N. Comparative study of the effect of dexamethasone injection and consumption in lower third molar surgery. Int J Oral Maxillofac Surg 2012;41:244-7. https://doi.org/10.1016/ j.ijom.2011.12.011

27. Kaewkumnert S, Phithaksinsuk K, Changpoo C, Nochit N, Muensaiyat Y, Wilaipornsawai S, et al. Comparison of intraosseous and submucosal dexamethasone injection in mandibular third molar surgery: a split-mouth randomized clinical trial. Int J Oral Maxillofac Surg 2020;49:529-35. https://doi.org/10.1016/ j.ijom.2019.10.006

28. de Santana-Santos T, de Souza-Santos aA, Martins-Filho PR, da Silva LC, de Oliveira E Silva ED, Gomes AC. Prediction of postoperative facial swelling, pain and trismus following third molar surgery based on preoperative variables. Med Oral Patol Oral Cir Bucal 2013;18:e65-70. https://doi.org/10.4317/medoral.18039

29. Rullo R, Addabbo F, Papaccio G, D’Aquino R, Festa VM. Piezoelectric device vs. conventional rotative instruments in impacted third molar surgery: relationships between surgical difficulty and postoperative pain with histological evaluations. J Craniomaxillofac Surg 2013;41:e33-8. https://doi.org/10.1016/j.jcms.2012.07.007

30. Latt MM, Chewpreecha P, Wongsirichat N. Prediction of difficulty in impacted lower third molars extraction; review literature. Mahidol Dent J 2015;35:281-90.

31. Majid OW, Mahmood WK. Use of dexamethasone to minimise post-operative sequelae after third molar surgery: comparison of five different routes of administration. Oral Surg 2013;6:200-8. https://doi.org/10.1111/ors.12049

32. Bodh R, Kumari S, Mohanty S, Kumar RD, Diana C. Removal of a deeply impacted ectopic mandibular third molar through a buccal corticotomy in severe trismus-a case report. J Clin Diagn Res 2018;12:ZD04-06. https://doi.org/10.7860/ JCDR/2018/29051.11077

33. Shah SA, Khan I, Shah HS. Effectiveness of submucosal dexamethasone to control postoperative pain \& swelling in apicectomy of maxillary anterior teeth. Int J Health Sci (Qassim) 2011;5:15665 .

34. Baxendale BR, Vater M, Lavery KM. Dexamethasone reduces pain and swelling following extraction of third molar teeth. Anaesthesia 1993;48:961-4. https://doi.org/10.1111/j.1365-2044.1993.tb07474. $\mathrm{x}$

35. Bamgbose BO, Akinwande JA, Adeyemo WL, Ladeinde AL, Arotiba GT, Ogunlewe MO. Effects of co-administered dexamethasone and diclofenac potassium on pain, swelling and trismus following third molar surgery. Head Face Med 2005;1:11. https://doi. org/10.1186/1746-160X-1-11

36. Graziani F, D'Aiuto F, Arduino PG, Tonelli M, Gabriele M. Perioperative dexamethasone reduces post-surgical sequelae of wisdom tooth removal. A split-mouth randomized double-masked clinical trial. Int J Oral Maxillofac Surg 2006;35:241-6. https://doi. org/10.1016/j.ijom.2005.07.010

37. Sood P, Ahuja G, Makkar D, Gaba R, Sidana J. Oral health related quality of life: perspectives. Dent J Adv Stud 2014;02:112-7. https://doi.org/10.1055/s-0038-1671996

38. Tiwana PS, Foy SP, Shugars DA, Marciani RD, Conrad SM, Phillips $\mathrm{C}$, et al. The impact of intravenous corticosteroids with third molar surgery in patients at high risk for delayed healthrelated quality of life and clinical recovery. J Oral Maxillofac Surg 2005;63:55-62. https://doi.org/10.1016/j.joms.2004.01.029

39. Fokunang C, Fokunang ET, Frederick K, Ngameni B, Ngadjui B. Overview of non-steroidal anti-inflammatory drugs (nsaids) in resource limited countries. MOJ Toxicol 2018;4:5-13. https://doi. org/10.15406/mojt.2018.04.00081

40. Kim K, Brar P, Jakubowski J, Kaltman S, Lopez E. The use of corticosteroids and nonsteroidal antiinflammatory medication for the management of pain and inflammation after third molar sur- 
gery: a review of the literature. Oral Surg Oral Med Oral Pathol Oral Radiol Endod 2009;107:630-40. https://doi.org/10.1016/ j.tripleo.2008.11.005

41. Benoliel R, Kahn J, Eliav E. Peripheral painful traumatic trigeminal neuropathies. Oral Dis 2012;18:317-32. https://doi.org/10.1111/ j.1601-0825.2011.01883.x

42. Alcântara CE, Falci SG, Oliveira-Ferreira F, Santos CR, Pinheiro ML. Pre-emptive effect of dexamethasone and methylprednisolone on pain, swelling, and trismus after third molar surgery: a splitmouth randomized triple-blind clinical trial. Int J Oral Maxillofac Surg 2014;43:93-8. https://doi.org/10.1016/j.ijom.2013.05.016

43. Gopinath KA, Chakraborty M, Arun V. Comparative evaluation of submucosal and intravenous dexamethasone on postoperative sequelae following third molar surgery: a prospective randomized control study. Int J Oral Care Res 2017;5:191-5.

44. Grossi GB, Maiorana C, Garramone RA, Borgonovo A, Beretta M, Farronato D, et al. Effect of submucosal injection of dexamethasone on postoperative discomfort after third molar surgery: a prospective study. J Oral Maxillofac Surg 2007;65:2218-26. https:// doi.org/10.1016/j.joms.2006.11.036

45. Schweizer A, Brom R, Glatt M, Bray MA. Leukotrienes reduce nociceptive responses to bradykinin. Eur J Pharmacol 1984;105:10512. https://doi.org/10.1016/0014-2999(84)90653-8

46. Lerner UH, Ransjö M, Ljunggren O. Bradykinin stimulates production of prostaglandin $\mathrm{E}_{2}$ and prostacyclin in murine osteoblasts. Bone Miner 1989;5:139-54. https://doi.org/10.1016/01696009(89)90092-5

47. Fernandes IA, de Souza GM, Pinheiro MLP, Falci SGM. Intramuscular injection of dexamethasone for the control of pain, swelling, and trismus after third molar surgery: a systematic review and meta-analysis. Int J Oral Maxillofac Surg 2019;48:659-68. https:// doi.org/10.1016/j.ijom.2018.09.014

48. Klongnoi B, Kaewpradub P, Boonsiriseth K, Wongsirichat N. Effect of single dose preoperative intramuscular dexamethasone injection on lower impacted third molar surgery. Int J Oral Maxillofac Surg 2012;41:376-9. https://doi.org/10.1016/j.ijom.2011.12.014

49. Bhargava D, Sreekumar K, Deshpande A. Effects of intra-space injection of Twin mix versus intraoral-submucosal, intramuscular, intravenous and per-oral administration of dexamethasone on postoperative sequelae after mandibular impacted third molar surgery: a preliminary clinical comparative study. Oral Maxillofac Surg 2014;18:293-6. https://doi.org/10.1007/s10006-013-0412-7

50. Sabhlok S, Kenjale P, Mony D, Khatri I, Kumar P. Randomized controlled trial to evaluate the efficacy of oral dexamethasone and intramuscular dexamethasone in mandibular third molar surgeries. J Clin Diagn Res 2015;9:ZC48-51. https://doi.org/10.7860/ JCDR/2015/13930.6813

51. de Sousa Santos JA, da Silva LC, de Santana Santos T, Menezes Júnior LR, de Assunção Oliveira AC, Brandão JR. Comparative study of tramadol combined with dexamethasone and diclofenac sodium in third-molar surgery. J Craniomaxillofac Surg 2012;40:694-700. https://doi.org/10.1016/j.jcms.2012.01.001

52. Nandini GD. Eventuality of dexamethasone injected intra-massetrically on post operative sequel following the surgical extraction of impacted mandibular third molars: a prospective study. J Maxillofac Oral Surg 2016;15:456-60. https://doi.org/10.1007/s12663-0150847-5

53. Arora SS, Phull T, Kumar I, Kumar A, Kumar N, Singh H. A comparative study of the effect of two dosages of submucosal injection of dexamethasone on postoperative discomfort after third molar surgery: a prospective randomized study. Oral Maxillofac Surg 2018;22:225-30. https://doi.org/10.1007/s10006-018-0699-5

54. Troiano G, Laino L, Cicciù M, Cervino G, Fiorillo L, D'amico C, et al. Comparison of two routes of administration of dexamethasone to reduce the postoperative sequelae after third molar surgery: a systematic review and meta-analysis. Open Dent J 2018;12:1818. https://doi.org/10.2174/1874210601812010181
55. Moraschini V, Hidalgo R, Porto Barboza Ed. Effect of submucosal injection of dexamethasone after third molar surgery: a metaanalysis of randomized controlled trials. Int J Oral Maxillofac Surg 2016;45:232-40. https://doi.org/10.1016/j.ijom.2015.09.008

56. Deo SP. Single-dose of submucosal injection of dexamethasone affects the post operative quality of life after third molar surgery. J Maxillofac Oral Surg 2016;15:367-75. https://doi.org/10.1007/ s12663-015-0846-6

57. Warraich R, Faisal M, Rana M, Shaheen A, Gellrich NC, Rana M. Evaluation of postoperative discomfort following third molar surgery using submucosal dexamethasone - a randomized observer blind prospective study. Oral Surg Oral Med Oral Pathol Oral Radiol 2013;116:16-22. https://doi.org/10.1016/j.oooo.2012.12.007

58. Moore PA, Brar P, Smiga ER, Costello BJ. Preemptive rofecoxib and dexamethasone for prevention of pain and trismus following third molar surgery. Oral Surg Oral Med Oral Pathol Oral Radiol Endod 2005;99:E1-7. https://doi.org/10.1016/j.tripleo.2004.08.028

59. Al-Dajani M. Can preoperative intramuscular single-dose dexamethasone improve patient-centered outcomes following third molar surgery? J Oral Maxillofac Surg 2017;75:1616-26. https://doi. org/10.1016/j.joms.2017.03.037

60. Vivek GK, Vaibhav N, Shafath A, Imran M. Efficacy of intravenous, intramassetric, and submucosal routes of dexamethasone administration after impacted third molar surgery: a randomized, comparative clinical study. J Adv Clin Res Insights 2017;4:3-7.

61. Latt MM, Kiattavorncharoen S, Boonsiriseth K, Pairuchvej V, Wongsirichat $\mathrm{N}$. The efficacy of dexamethasone injection on postoperative pain in lower third molar surgery. J Dent Anesth Pain Med 2016;16:95-102. https://doi.org/10.17245/jdapm.2016.16.2.95

62. Moranon P, Chaiyasamut T, Sakdajeyont W, Vorakulpipat C, Klongnoi B, Kiattavornchareon S, et al. Dexamethasone injection into pterygomandibular space versus sublingual space on postoperative sequalae of lower third molar intervention. J Clin Med Res 2019;11:501-8. https://doi.org/10.14740/jocmr3844

63. Majid OW, Mahmood WK. Effect of submucosal and intramuscular dexamethasone on postoperative sequelae after third molar surgery: comparative study. Br J Oral Maxillofac Surg 2011;49:64752. https://doi.org/10.1016/j.bjoms.2010.09.021

64. Chaudhary PD, Rastogi S, Gupta P, Niranjanaprasad Indra B, Thomas R, Choudhury R. Pre-emptive effect of dexamethasone injection and consumption on post-operative swelling, pain, and trismus after third molar surgery. A prospective, double blind and randomized study. J Oral Biol Craniofac Res 2015;5:21-7. https:// doi.org/10.1016/j.jobcr.2015.02.001

65. Ngeow WC, Lim D. Do corticosteroids still have a role in the management of third molar surgery? Adv Ther 2016;33:1105-39. https://doi.org/10.1007/s12325-016-0357-y

66. Latif Shah K, Saud Al Lbad A, Al Anazi YM, Ahmad Al Khalaf Y, Mohammed Balto M, Jaafar Albahrani Z. Comparison of therapeutic effects of $8 \mathrm{mg}$ dexamethasone intramuscular administered pre-operatively vs. post operatively after the surgical extraction of impacted mandibular third molars. Dent Craniofac Res 2018;03:9. https://doi.org/10.21767/2576-392x.100025

67. Núñez-Díaz D, Chumpitaz-Cerrate V, Chávez-Rimache L, Cruz LGS. Comparison of the anti-inflammatory effectiveness of dexamethasone as pre-surgical and post-surgical therapy in mandibular third molar surgery: a randomized clinical trial. J Oral Res 2020;8: 463-70. https://doi.org/10.17126/joralres.2019.0

68. Markiewicz MR, Brady MF, Ding EL, Dodson TB. Corticosteroids reduce postoperative morbidity after third molar surgery: a systematic review and meta-analysis. J Oral Maxillofac Surg 2008;66: 1881-94. https://doi.org/10.1016/j.joms.2008.04.022

69. Mehra P, Reebye U, Nadershah M, Cottrell D. Efficacy of antiinflammatory drugs in third molar surgery: a randomized clinical trial. Int J Oral Maxillofac Surg 2013;42:835-42. https://doi. org/10.1016/j.ijom.2013.02.017

70. Lima CAA, Favarini VT, Torres AM, da Silva RA, Sato FRL. Oral 
dexamethasone decreases postoperative pain, swelling, and trismus more than diclofenac following third molar removal: a randomized controlled clinical trial. Oral Maxillofac Surg 2017;21:321-26. https://doi.org/10.1007/s10006-017-0635-0

71. Sitthisongkhram K, Niyomtham N, Chaiyasamut T, Pairuchvej V, Kc K, Wongsirichat N. Effectiveness of dexamethasone injection in the pterygomandibular space before and after lower third molar surgery. J Dent Anesth Pain Med 2020;20:313-23. https://doi. org/10.17245/jdapm.2020.20.5.313

72. Darawade DA, Kumar S, Mehta R, Sharma AR, Reddy GS. In search of a better option: dexamethasone versus methylprednisolone in third molar impaction surgery. J Int Oral Health 2014;6:147.

73. Lim D, Ngeow WC. A comparative study on the efficacy of submucosal injection of dexamethasone versus methylprednisolone in reducing postoperative sequelae after third molar surgery. J Oral Maxillofac Surg 2017;75:2278-86. https://doi.org/10.1016/ j.joms.2017.05.033

74. García AG, Sampedro FG, Rey JG, Vila PG, Martin MS. PellGregory classification is unreliable as a predictor of difficulty in extracting impacted lower third molars. Br J Oral Maxillofac Surg 2000;38:585-7. https://doi.org/10.1054/bjom.2000.0535

75. Capuzzi P, Montebugnoli L, Vaccaro MA. Extraction of impacted third molars. A longitudinal prospective study on factors that af- fect postoperative recovery. Oral Surg Oral Med Oral Pathol 1994;77:341-3. https://doi.org/10.1016/0030-4220(94)90194-5

76. Caplan A, Fett N, Rosenbach M, Werth VP, Micheletti RG. Prevention and management of glucocorticoid-induced side effects: a comprehensive review: gastrointestinal and endocrinologic side effects. J Am Acad Dermatol 2017;76:11-6. https://doi.org/10.1016/ j.jaad.2016.02.1239

77. Bebawy JF. Perioperative steroids for peritumoral intracranial edema: a review of mechanisms, efficacy, and side effects. J Neurosurg Anesthesiol 2012;24:173-7. https://doi.org/10.1097/ ANA.0b013e3182578bb5

78. Laino L, Menditti D, Lo Muzio L, Laino G, Lauritano F, Cicciù M. Extraoral surgical approach of ectopic mandibular third molar to the lower border of mandible. J Craniofac Surg 2015;26:e256-60. https://doi.org/10.1097/SCS.0000000000001541

How to cite this article: Selvido DI, Bhattarai BP, Niyomtham N, Riddhabhaya A, Vongsawan K, Pairuchvej V, et al. Review of dexamethasone administration for management of complications in postoperative third molar surgery. J Korean Assoc Oral Maxillofac Surg 2021;47:341-350. https://doi.org/10.5125/jkaoms.2021.47.5.341 